\title{
Foreign Direct Investment and the Pollution Haven Hypothesis in Indonesia
}

\author{
Shofwan Shofwan \\ University of Brawijaya, Indonesia \\ Michelle Fong \\ Victoria University, Australia
}

\begin{abstract}
This paper investigates the validity of the pollution haven hypothesis in the context of Foreign Direct Investment (FDI) in Indonesia by determining the correlations between carbon emission and foreign direct investment, gross domestic product, and population size between 1975 and 2009 in that country. Statistical results from Spearman's correlation analysis show that $\mathrm{CO}_{2}$ emission has a statistically significant negative relationship with real Gross Domestic Product (GDP), and a statistically significant positive relationship with population size in the Indonesian economy between 1975 and 2009. However, there is a weak and insignificant relationship between $\mathrm{CO}_{2}$ emission and real FDI during this period which indicates weak support for the pollution haven hypothesis because FDI does not appear to be as strong a contributing factor to $\mathrm{CO}_{2}$ emission as the activities of the population in Indonesia.
\end{abstract}

\section{KEYWORDS}

Climate change, carbon emissions, pollution, foreign direct investment, haven hypothesis

\section{INTRODUCTION}

Until the 1960s, the understanding of the impact of Foreign direct investment (FDI) was largely grounded on the theory of international factor movements, which was itself founded on the premise that differences in the relative capital endowments and marginal efficiency of capital among countries will lead to flows of investment from rich to poor countries (Hennart, 1982). Over the subsequent decades, the growing interest in FDI (for its growth-enhancing potential in economic development) has led to the development of various theories and approaches attempting to explain why Multinational Enterprises (MNEs) engaged in FDI (Moosa, 2002). The theories all offer theoretical paradigms to explain the causes and consequences of FDI and include eclectic theory (Dunning, 1981); internalisation theory (Buckley and Casson, 1976); product life cycle theory (Vernon, 1966; Hirsch, 1976); multinational enterprise theory (Buckley and Casson, 1981; 1991); and market imperfections theory (Kindleberger, 1969). While market size and potential, trade barriers, trade opportunities (exports and imports), exchange rates, interest rates, wage rates, inflation rates, and country risk were some of the main FDI determinants explicitly identified by these theories, environmental-based factors (such as differential environmental regulations) were not conceived as strong determinants of FDI until the 1990s when environmental concerns became an important topic in the global trade agenda (Jayadevappa and Chhatre, 2000).

Although awareness of the relationship between environmental quality and international trade was initially raised in the late 1970s, public debate on this relationship only began to surface in the 1980s, during negotiation rounds of the North American Free Trade Agreement (NAFTA), the Uruguay round of the General Agreement on Tariffs and trade (GATT) negotiations, and the formation of the World Trade Organization (WTO) (Jayadevappa and Chhatre, 2000). FDI is a field of discipline within the broad area of international 
trade and the environmental impact of FDI inflow on developing countries had also begun to attract polemical and polarised debates among scholars, policy makers, foreign investors, environmentalists and free trade supporters by the 1980s. Academic debate on the 'pollution haven phenomenon' began to emerge in publications in the 1990s (Neumayer, 2001). This concept postulates that foreign investors from industrial countries are attracted to weak environmental regulations in developing countries, and thus turn the latter into "havens" for the world's polluting industries. At the same time, this debate also gave rise to the "pollution halo theory', a notion that is in stark contrast to the pollution haven phenomenon. The 'pollution halo theory' suggests that foreign firms can improve the environmental performance in host countries by their transfer of superior technology and management principles from their home countries to these countries. Proponents of freer trade have argued that FDI has increased economic growth and transferred new knowledge and technologies to developing countries, as well as encouraging the adoption of integrated economies in host countries (Bora, 2002; Blaine 2009; MacDermott, 2009a). Although there has been a plethora of literature attempting to determine the validity of either of the pollution haven or pollution halo hypotheses, empirical evidence on the environmental impact of FDI inflow on developing countries has been inconclusive.

\section{Pollution Haven Hypothesis and Pollution Halo Hypothesis}

The pollution haven phenomenon hypothesizes that foreign investors tend to move to countries that apply lower environmental standards than in their own country and that such host countries tend to be less developed and to have relatively lax environmental protection (Copeland and Taylor, 1994). The end result is that poorer nations become 'pollution havens'. Copeland and Taylor (1994) were the first researchers to model this hypothesis and their work was supported by other studies by He (2006), Spatareanu (2007), Cave and Blomquist (2008) and MacDermott (2009b). However, other studies were unable to support this claim (Jayadevappa and Chhatre, 2000). Research undertaken by Dean (1992), Wheeler and Moddy (1992), Zarsky (1999), Eskeland and Harrison (2003), Smarzynska and Wei (2004), and Dean, et al. (2005) found little evidence for the pollution haven hypothesis. Conversely, some studies in support of the pollution halo hypothesis reported that foreign direct investment brings improvements in environmental performance in developing countries. Blackman and $\mathrm{Wu}(1998)$ found that foreign investment in electricity generation in China increased energy efficiency and reduced emissions. Letchumanan and Kodama's (2000) case study found anecdotal evidence of a transfer of cleaner products and processes by a foreign investor to a developing host country. Eskeland and Harrison's (2003) study argued that foreign firms are significantly more energy efficient and adopt cleaner types of energy than local firms.

\section{About this Paper and the Variables}

This paper aims to investigate the validity of the pollution haven hypothesis in the context of FDI in Indonesia. It utilizes Spearman's correlation to investigate the relationship between carbon emission and foreign direct investment, gross domestic product, and population size between 1975 and 2009.

In 2009, Indonesia's National Climate Change Council reported that the country was the world's third largest greenhouse emitter (Fogarty, 2009). Besides rainforests and forest fires, the industry segment was also identified as a responsible party in greenhouse gas emission in the Indonesian economy (Resosudarmo and Irhamni, 2008). The problem of $\mathrm{CO}_{2}$ emission in Indonesia was first noted in the 1970s when the industrial sector started to grow and in 2002, the industrial environmental performance in several large cities in Java (where FDI has been concentrated in this region) were showing $\mathrm{CO}_{2}$ emission as high as 10 million tonnes. In terms of $\mathrm{CO}_{2}$ intensity for all sectors within the economy, there was an increase of 31 percent in metric tonnes per US\$2,000 of GDP between 1990 and 2002. However, this problem must also be seen as a function of population growth. Hence, in this study $\mathrm{CO}_{2}$ emissions are treated as the dependent variable with population, GDP and FDI as independent variables in a Spearman correlation analysis. 


\section{Indonesia}

FDI inflows to Indonesia constituted 1.9 percent of GDP in 2010, which can be considered relatively low, compared to 2.3 percent in Brazil and more than 7 percent in Chile (The World Bank, 2011). Indonesia used to enjoy a robust flow of FDI into its economy prior to a period of economic and political instability in 1999 and 2000. In 1989, it had 40 percent of the FDI in ASEAN (Association of South East Asian Nation) ${ }^{1}$ and was the third largest recipient after Singapore and Malaysia. Indonesia had also been a major recipient of FDI for the three decades prior to the 1997 Asian financial crisis (Ramasamy \& Yeung 2004). Despite the regional downturn between 1997 and 1998, Indonesia was able to accumulate US\$60 billion and become the most favoured FDI location in ASEAN. However, inflows of FDI into Indonesia declined substantially during the period of economic and political instability in 1999 and 2000 (Ramasamy and Yeung, 2004; Adiningsih, 2007; Ismail, 2009). The flows of FDI into this country slowly began to recover during the early 2000s, but although they helped to re-stimulate the economy (Ramasamy and Yeung, 2004), the influx and its impact failed to match its past vigour. The cumulative inflows in 2010 amounted to US\$13.3 billion, less than onequarter of the amount achieved between 1997 and 1998(The World Bank, 2011).

The Indonesian government has recognized FDI as a potential source of economic development and growth, and poverty alleviation (The World Bank 2011). At the same time, it also faces challenges from these FDI inflows - one of which relates to the environmental sustainability of the investment. Although FDI flows have been facilitating Indonesia's economic growth, they have also been associated with alarming levels of environmental pollution (Resosudarmo \& Irhamni 2008). The environmental degradation has been predicted to escalate by more than 50 percent between 2010 and 2020 (Hitipieuw 2011). Some of the factors aggravating this environmental deterioration have been identified by Hitipeuw (2011). They include the unrestrained issuance of operational licenses to big mining and paper companies by both central and local governments, weak enforcement of disposal threshold for companies' waste, and the absence of government regulations on spatial planning and guidelines for environmental research. Abimanyu (2000) and Bedner (2010) highlighted that weak enforcement of legislation and regulations, absence of government support for environmental sustainability planning and research in Indonesia, a trade liberalisation policy, and the consequences of decentralisation in Indonesian provinces may give an impression to foreign investors that the country has relatively lax environmental standards.

However, there have been indications in recent years that the Indonesian government is taking a more serious stand on domestic environmental issues. The number of emission warnings issued by the government to foreign companies has increased. Five foreign companies were issued with emission warnings from the Indonesian government in 2010, but twenty-two such warnings were issued between January and July 2011. However, it should not be immediately inferred that foreign companies are primarily responsible for damaging the environment; those companies issued with a warning constituted only $1.5 \%$ (in 2010) and 6.9\% (in 2011) of the foreign investing community in Indonesia, which are not significant proportions when all domestic and foreign businesses are taken into consideration. In its move to tighten environmental control, the government has suspended the operations of some foreign companies which failed to comply with the first warning, and has tried to launch legal proceeding against two companies which were suspected of serious environmental pollution. For example, in one high-profile case the Newmont Mining Corporation, the world's biggest gold producer, and its Indonesian chief executive were put on criminal trial in August 2004 for contaminating one of Indonesia's water bays, poisoning marine life and inflicting health problems on villagers residing in the area. This case was closely observed by the foreign investor community, business groups and

\footnotetext{
${ }^{1}$ ASEAN members are Brunei Darussalam, Cambodia, Indonesia, Laos, Malaysia, Myanmar, Philippines, Singapore, Thailand, and Vietnam.
} 
environmentalists worldwide, because its verdict promised to have considerable impact on future FDI inflows and judicial implications for similar cases involving foreign corporations. On November 15, 2005, the Indonesian court dismissed the suit on the technical grounds that the government had breached the terms of its contract with Newmont Mining Corporation by taking legal action before seeking arbitration. To date, there have been few such attempts to prosecute foreign companies for environmental damage, and with little success. In terms of empirical evidence and data, there is still little concrete proof of FDI being responsible for environmental damage in Indonesia.

\section{Methodology, Variables, and Results}

Table 1 shows the descriptive statistics on $\mathrm{CO}_{2}$ emission, real GDP, population size, and real FDI in Indonesia between 1975 and 2009. The data distribution for foreign direct investment suggests a skewed distribution. As a result, this paper utilizes Spearman's correlation to investigate the relationship between Indonesia's carbon emission and foreign direct investment, gross domestic product, and population between 1975 and 2009 . This nonparametric correlation method is used because it is not constrained by the distribution of the data.

Table 1: Descriptive statistics on $\mathrm{CO}_{2}$ emission, real GDP, Population and real FDI in Indonesia between 1975 and 2009.

\begin{tabular}{lcccc}
\hline & Mean & Median & Standard deviation & $\mathrm{N}$ \\
\hline $\begin{array}{l}\mathrm{CO}_{2} \text { emission (in metric } \\
\text { tonnes) }\end{array}$ & $204,015,518.28$ & $202,410,358.63$ & $110,163,466.63$ & 35 \\
$\begin{array}{l}\text { Real GDP (in US\$ } \\
\text { million), base year }\end{array}$ & $819,216.76$ & $895,694.33$ & $346,985.59$ & 35 \\
$=2009$ & $182,043,000$ & $183,119,000$ & $29,747,000$ & 35 \\
$\begin{array}{l}\text { Population } \\
\text { Real FDI (in US\$ }\end{array}$ & $38,092.92$ & $21,829.69$ & $46,309.30$ & 35 \\
million), base year & & & \\
$=2009$
\end{tabular}

Figure 1 shows an upward trend in $\mathrm{CO}_{2}$ emission between 1975 and 2009. The estimated average increase in $\mathrm{CO}_{2}$ emission per year was $10,409,007.77$ metric ton. This graph shows a reduction in $\mathrm{CO}_{2}$ emission between 1998 and 2000 followed by renewed growth from 2001 onwards. 


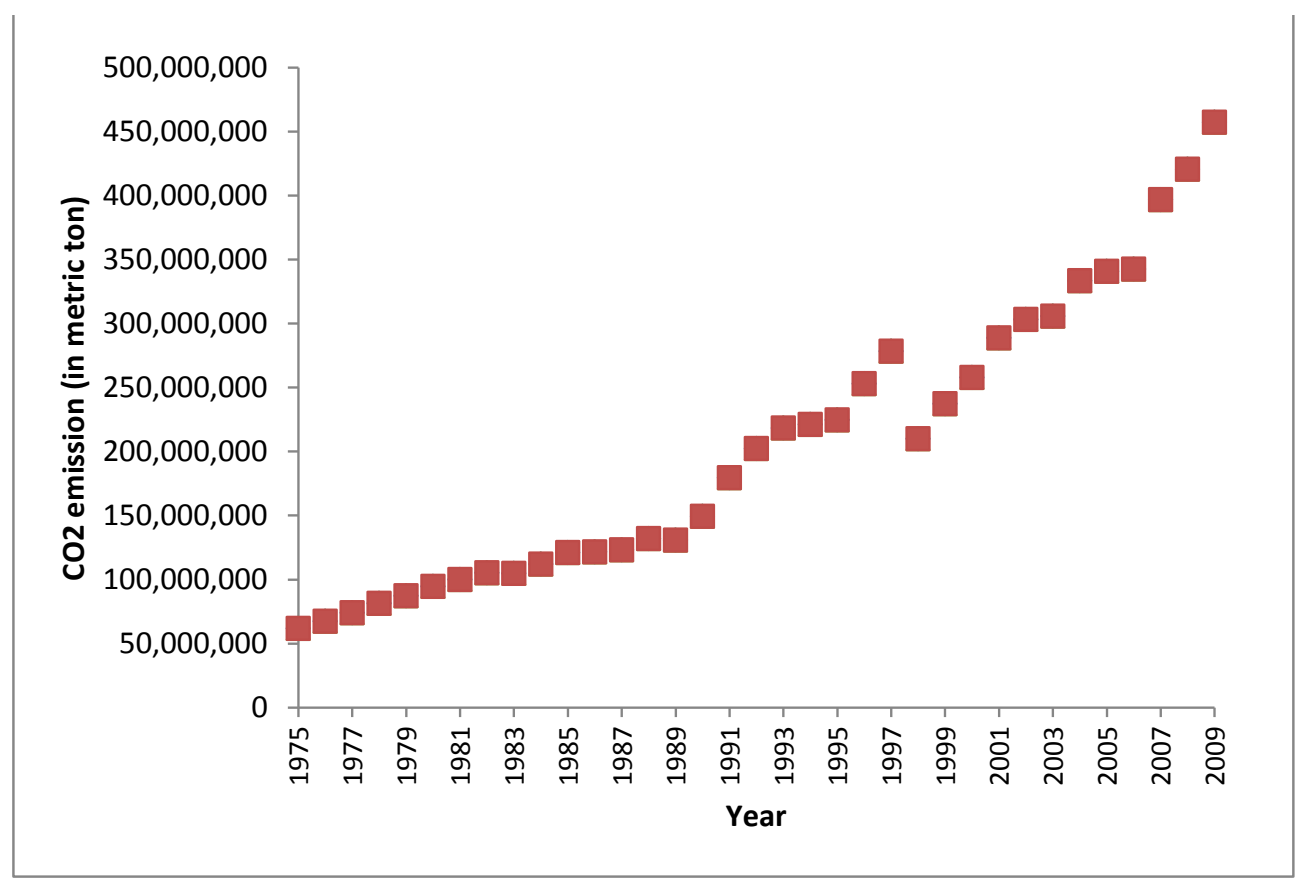

Figure 1: $\mathrm{CO}_{2}$ emission (in metric ton) between 1975 and 2009

Table 2: Results from Spearman's correlation.

\begin{tabular}{lcc}
\hline & $\mathrm{CO}_{2}$ emission & $\mathrm{N}$ \\
\hline Real GDP & $-0.759^{* *}$ & 35 \\
Population & $0.993^{* *}$ & 35 \\
Real FDI & 0.070 & 35 \\
& \\
\hline$*$ Correlation is significant at the 0.01 level.
\end{tabular}

The Spearman's correlation coefficients show $\mathrm{CO}_{2}$ emission having a statistically significant negative relationship $(p<0.01)$ with real GDP, and a statistically significant positive relationship $(p<0.01)$ with population size in the Indonesian economy between 1975 and 2009. However, there is a weak and insignificant relationship between $\mathrm{CO}_{2}$ emission and real FDI during this period. The statistically significant negative relationship between $\mathrm{CO}_{2}$ emission and real GDP suggests that $\mathrm{CO}_{2}$ emission decreases as real GDP increases, while the statistically significant positive relationship between $\mathrm{CO} 2$ emission and population size suggests that $\mathrm{CO}_{2}$ emission increases with the growth in population.

\section{Discussion}

The Spearman's correlation results suggest that FDI may not as strong an influence on $\mathrm{CO}_{2}$ emission as the activities of the population (population size being the proxy variable) in Indonesia. The statistical results appeared not to be supportive of the pollution haven hypothesis, because FDI does not have a significant relationship with $\mathrm{CO}_{2}$ emission.

Some studies suggest that environmental regulation is not the only reason behind the decision of a MNE to relocate its plants, and that other factors may be involved. Tole and Koop (2011) find that preferences among 
multinational gold mining firms to relocate their operations are contingent upon proximity to head office, provision of a business environment characterised by low levels of financial risk and high levels of political stability, and predictability in mining operations. Pargal and Mani (2000) similarly find that plant owners choose a new location based on aspects like low land price and rich natural resources. Dean (2001) and Jaffe et al (1995) reveal that environmental stringency is just one factor in location decisions, and not a very significant one, compared to other country factor endowments such as cheap and skilled labour amd quality of infrastructure. Similarly, Mani's (1996) study on plant location decisions found that plant relocation is not affected by the level of environmental stringency in the home country. Bommer (1999) also shows evidence that stringent environmental control in the home country is not the only reason for a firm to relocate to other countries with relatively lax environmental regulations; relocation may be based on strategic reasons such as opportunities to reduce production costs, increase profits and increase market value.

Hence, further research at the micro level is recommended to increase understanding of the environmental sustainability of FDI in Indonesia and to determine the relevance of the pollution halo hypothesis in regard to such investment. Collins and Harris (2002) found plant-level evidence suggesting that foreign-owned firms spend more on pollution abatement to improve the environment than do domestic-owned firms, after controlling for productivity efficiency and pollution control policies issued by governments. Their study attributed such spending behaviour to characteristics of ownership and efficiency in a firm's decision making. Similarly, Bhagwati (2004) argued that some industrial firms which originate from richer countries, have higher environmental standards and adopt more innovative processes and newer and cleaner technology in order to produce environmentally-friendly products. These firms were also found to have implemented the strict environmental sustainability rules of their home countries even in locations where the environmental standards were weak. Konar and Cohen (2001) investigated the relationship between the environmental sustainability behaviour of firms and their financial performance, in an attempt to measure their market value. They found that some large companies which are listed in stock exchanges market such as the New York Stock Exchange (NYSE) would spend money on improving their environmental reputation in order to enhance their market values. These companies tend to voluntarily over-comply with environmental regulations and seek to portray an external image of being environmentally concerned. This suggests that the pollution haven hypothesis is not applicable when such companies sought to increase their corporate values by being environmentally responsible. The pollution halo hypothesis, on the other hand, may have relatively more validity in such situation.

Another area that also warrants future investigation is the relationship between $\mathrm{CO}_{2}$ emission and real GDP under the Environmental Kuznets Curve (EKC). This may offer an explanation for the weak support of the pollution haven hypothesis offered by the data presented in this paper. The EKC describes the relationship between economic growth and pollution level when a developing country becomes a developed nation, specifically, it suggests that economic growth initially increases the pollution level, until an economy reaches a certain size, and decreases thereafter (Grossman and Krueger, 1995; Kearsley and Riddel, 2010). According to the EKC, this relationship between economic growth and pollution level should present as an inverted Ushaped. The curve postulates that pollution decreases when a developing nation becomes a developed nation, because of enhanced economies of scale and trade openness policy. Cole (2004) found that when a country achieves a higher level of income, it may increase both its demand for environmental regulations and its investment in abatement technologies, which results in a negative relationship between economic growth and pollution level. If this concept is valid and the host country improves its environment regulations, MNE will be forced to step into line, thus negating the pollution problem once this country achieved developed nation status. The statistically significant negative relationship between $\mathrm{CO}_{2}$ emission and real GDP appears to follow the downward slope of the EKC. However, Indonesia is clearly still a developing country, not a developed country on the downward slope of the EKC, which warrants further investigation. In fact, the EKC appears to have weak empirical support and has not successfully been proven to apply to all pollutants or environmental impacts (Dasgupta et al., 2022; Perman and Stern, 2003) and therefore may not exist.

\section{CONCLUSION}

This paper investigates the validity of the pollution haven hypothesis in the context of FDI by determining the correlations between Indonesia's carbon emission and foreign direct investment, gross domestic product, and 
population size between 1975 and 2009. Statistical results from Spearman's correlation analysis show that $\mathrm{CO}_{2}$ emission has a statistically significant negative relationship with real GDP, and a statistically significant positive relationship with population size in the Indonesian economy between 1975 and 2009. However, there is a weak and insignificant relationship between $\mathrm{CO}_{2}$ emission and real FDI during this period which suggests weak support for the pollution haven hypothesis because FDI does not appear to be as strong a contributing factor to $\mathrm{CO}_{2}$ emission as the activities of the population (population size being the proxy variable) in Indonesia. The paper proposes further research investigation into the environmental sustainability of FDI in Indonesia through firm-level data analysis, particularly for determining the relevance of the pollution halo hypothesis to FDI in this country. The paper also suggests further work to investigate the applicability of the EKC on the statistically significant negative relationship between $\mathrm{CO}_{2}$ emission and real GDP in Indonesia. This may offer a different perspective on, or explanation of the validity of the pollution haven hypothesis for FDI in Indonesia, as well as that of the EKC theory itself, since Indonesia still holds a developing nation status.

\section{REFERENCES}

Abimanyu, A., 2000. Impact of agriculture trade and subsidy policy on the macroeconomy, distribution, and environment in Indonesia: A strategy for future industrial development. The Developing Economies, 38(4), 547-571.

Adiningsih, S., 2007. Indonesia: Ten years after the economic crisis. IDS Bulletin, 38(4), 45-58.

Bedner, A. 2010. Consequence of decentralisation: Environmental impact assessment and water pollution control in Indonesia. Law \& Policy, 32(1), 38-60.

Bhagwati, J.N., 2004. In Defense of Globalization, New York: Oxford University Press,.

Blackman, A. and Wu, X., 1998. Foreign direct investment in China's power sector: Trends, benefits, and barriers. Resource for the Future, Washington DC.

Blaine, H.G., 2009. Foreign direct investment. New York: Nova Science Publishers.

Bommer, R., 1999. Environmental Policy and Industrial Competitiveness: The Pollution Haven Hypothesis Reconsidered. Review of International Economics, 7(2), 342-355.

Bora, B., 2002. 'FDI and the environment: The link between FDI and the environment', in B. Bora (ed.), Foreign Direct Investment: Research Issues, London: Routledge.

Buckley, P.J. and Casson, M., 1976. The future of multinational experience. New York: Homes and Meier Publishers.

Buckley, P.J. and Casson, M., 1981. The optimal timing of a foreign direct investment. Economic Journal, 91(361), 75-87.

Buckley, P.J. and Casson, M., 1991. The future of the multinational experience. London: Macmillan.

Cave, L.A. and Blomquist, G.C., 2008. Environmental policy in the European Union: Fostering the development of pollution havens? Ecological Economics, 65(2), 253-261.

Cole, M.A., 2004. Trade, the pollution haven hypothesis and the environmental Kuznets curve: examining the linkages. Ecological Economics, 48(1), 71-81.

Collins, A. and Harris, R.I.D., 2002. Does plant ownership affect the level of pollution abatement expenditure? Land Economics, 78(2), 171.

Copeland, B.R. and Taylor, M.S., 1994. North-South trade and the environment. The Quarterly Journal of Economics, 109(3), 755-87.

Dasgupta, S., Laplante, B., Wang, H., and Wheeler, D., 2002. Confronting the environmental Kuznets curve. Journal of Economic Perspectives, 16, 147-168.

Dean, J.M., 1992. Trade and environment: A survey of the literature. Working Paper No. 966. World Bank, Policy Research Department.

Dean, J.M., Lovely, M.E., and Wang, H., 2005. Are foreign investors attracted to weak environment regulations? Evaluating the evidence from China. Working Paper No. 3505. World Bank, Policy Research Department.

Dean, J.M., 2001, International Trade and Environment. UK: Ashgate Publisher.

Eskeland, G.S. and Harrison, A.E., 2003. Moving to greener pastures? Multinationals and the pollution haven hypothesis. Journal of Development Economics, 70(1), 1-23. 
Fogarty, D., 2009. Indonesia CO2 pledge to help climate talks-greens. Retreived on 22 September 2011 from http://www.reuters.com/assets/print?aid=USSP495601

Grossman, G.M. and Krueger, A.B., 1995. Economic growth and the environment. The Quarterly Journal of Economics, 110(2), 353-377.

He, J., 2006. Pollution haven hypothesis and environmental impacts of foreign direct investment: The case of industrial emission of sulfur dioxide (SO2) in Chinese provinces. Ecological Economics, 60(1), 228245.

Hennart, J.F., 1982. A theory of multinational enterprise. Ann Arbor: The University of Michigan Press.

Hirsch, S., 1976. An international trade and investment theory of the firm. Oxford Economic Papers, 28(2), 258-270.

Hitipieuw, J., 2011. Indonesia faces serious threat of environemntal damage this year. KOMPAS, 13 January, p. 1.

Ismail, N.W., 2009. The Determinant of Foreign Direct Investment in ASEAN: A Semi-Gravity Approach. Transition Studies Review, 16(3), 710-722.

Jaffe, A.B., Peterson, S.R., Portney, P.R. and Stavins, R.N., 1995. Environmental regulation and the competitiveness of US manufacturing: what does the evidence tell us? Journal of Economic literature, 33(1), 132-163.

Jayadevappa, R. and Chhatre, S., 2000. International trade and environmental quality: A survey. Ecological Economics, 32, 175-194.

Kearsley, A. and Riddel, M., 2010. A further inquiry into the Pollution Haven Hypothesis and the Environmental Kuznets Curve. Ecological Economics, 69(4), 905-919.

Kindleberger, C.P., 1969. American business abroad: Six lectures on direct investment. New Haven: Yale University Press.

Konar, S. and Cohen, M.A., 2001. Does the market value environmental performance? Review of Economics and Statistics, 83(2), 281-289.

Letchumanan, R. and Kodama, F., 2000. Reconciling the conflict between the 'pollution-haven' hypothesis and an emerging trajectory of international technology transfer. Research Policy, 29(1), 59-79.

MacDermott, R., 2009a. 'Environmental regulations and the flow of foreign direct Investment: A review of the pollution haven hypothesis', in HG Blaine (ed.), Foreign direct investment, Nova Science Publishers, New York, pp. 145-54.

MacDermott, R., 2009b. A panel study of the pollution haven hypothesis. Global Economy Journal, 9(1), 112.

Mani, M.S., 1996. Environmental tariffs on polluting imports. Environmental and Resource Economics, 7(4), $391-411$.

Moosa, I.A., 2002. Foreign direct investment: Theory, evidence and practice. New York: Palgrave.

Neumayer, E., 2001. Pollution havens: An analysis of policy options for dealing with an elusive phenomenon. Journal of Environment and Development, 10(2), 147-177.

Pargal, S. and Mani, M., 2000. Citizen activism, environmental regulation, and the location of industrial plants: evidence from India. Economic Development and Cultural Change, 48(4), 829-46.

Perman, R. and Stern, D. I., 2003. Evidence from panel unit root and cointegration tests that the environmental Kuznets curve does not exist. Australian Journal of Agricultural and Resource Economics, 47(3), 325-347.

Ramasamy, B. and Yeung, M. 2004. 'The European Union's foreign direct investment into Indonesia: Determinants and threats', in HS Kehal (ed.), Foreign Investment in Developing Countries, Palgrave Macmillan, New York.

Resosudarmo, B.P. and Irhamni, M., 2008. Indonesia's industrial policy reforms and their environmental impacts. Journal of the Asia Pacific Economy, 13(4), 426-50.

Resosudarmo, B.P. and Irhamni, M., 2008. Indonesia's industrial policy reforms and their environmental impacts. Journal of the Asia Pacific Economy, 13(4): 426-450.

Smarzynska, B. and Wei, S.J., 2004. Pollution havens and foreign direct investment: Dirty secret or popular myth? Contributions to Economic Analysis \& Policy, 3(2), 1244-1244.

Spatareanu, M., 2007. Searching for pollution havens: The impact of environmental regulations on foreign direct investment. The Journal of Environment \& Development, 16(2), 161-182.

The World Bank, 2011, Indonesia Economic Quarterly: Current challenges, future potential. The World Bank, June. $\quad$ Retrieved on 15 October, 2011 from: http://www- 
wds.worldbank.org/external/default/WDSContentServer/WDSP/IB/2011/07/07/000356161 20110707 031751/Rendered/PDF/631430WP0ENGLI00BOX361502B00PUBLIC0.pdf

Tole, L. and Koop, G., 2011. Do environmental regulations affect the location decisions of multinational gold mining firms? Journal of Economic Geography, 11(1): 151-177.

Vernon, R., 1966. International investment and international trade in the product cycle. Quarterly Journal of Economics, 80(2), 190-207.

Wheeler, D. and Moody, A., 1992. International investment location decisions: The case of US firms. Journal of International Economics, 33, 57-76.

Zarsky, L., 1999. 'Havens, halos and spaghetti: Untangling the evidence about foreign direct investment and the environment', in OECD (ed.), Foreign Direct Investment and the Environment, OECD, Paris, pp. 47-74. 
